\title{
Mixed pneumoconiosis due to silicates and hard metals associated with primary Sjögren's syndrome due to silica
}

\author{
Pneumoconiose mista por silicatos e metais duros associada à \\ síndrome de Sjögren primária por silicatos
}

\section{Pedro Gonçalo de Silva Ferreira, António Jorge Correia Gouveia Ferreira, Lina Maria Rodrigues de Carvalho, António Segorbe Luís}

\section{To the Editor:}

Here, we describe the case of a 75-year-old man who presented with a 3-year history of progressive dyspnea on exertion (classified as grade 11/111 on the modified Medical Research Council scale) and persistent dry cough. He had worked as a professional welder for 35 years, welding alloys, polishing weldments by sandblasting and steel blasting, and regularly performing isolation of fixed appliances with asbestos fibers.

Treated in the primary care setting in the first year, the patient developed recurrent scaly skin lesions (exhibiting a lichenified/desquamative pattern) on the limbs, Raynaud's phenomenon, sicca syndrome, and weight loss (5 kg). Physical examination revealed that he was breathing normally, with an $\mathrm{SpO}_{2}$ of 95\% and auscultatory findings of basal inspiratory crackles, and that there was no digital clubbing.

$A$ chest $X$-ray showed reticular interstitial changes. A CT scan of the chest showed calcified mediastinal adenopathy exhibiting an "eggshell" pattern, interlobular reticulation, traction bronchiectasis, and septal thickening, as well as areas of ground-glass opacity, alveolar consolidation with a peribronchovascular distribution, and areas of pleural thickening (Figure 1).

The patient underwent a skin biopsy, which showed non-specific lichenoid changes. A BAL, performed at the level of the middle lobe (right bronchus, 4a), revealed a total cell count of 130,000 cells/mL, with 40\% lymphocytes and 16\% neutrophils, as well as negative microbiological and cytological findings. Immunophenotyping showed a predominance of CD8 T lymphocytes $(C D 4 / C D 8$ ratio $=0.68)$ and B lymphocytes $(20 \%)$. The inorganic fraction showed no asbestos bodies and was sent for determination of the levels of hard metals and silicates by inductively coupled plasma-atomic emission spectrometry. This study showed high levels of silica, copper, cobalt, chromium, rubidium, molybdenum, and zinc.

Laboratory testing revealed that the patient had a hemoglobin level of $11.6 \mathrm{~g} / \mathrm{dL}$, normal inflammatory markers, a creatinine level of 1.0 $\mathrm{mg} / \mathrm{dL}$, and an inactive urinary sediment, as well as having a beta-2 microglobulin level of 6.56 $\mathrm{mg} / \mathrm{L}$ and a serum angiotensin-converting enzyme level of $127 \mathrm{U} / \mathrm{L}$. In addition, he had polyclonal hypergammaglobulinemia ( $\lg \mathrm{G}$ and $\lg \mathrm{A})$ and positive antinuclear antibodies (anti-SSA60 and anti-SSB antibodies) at high titers. Schirmer's test confirmed xerophthalmia (right eye, $9 \mathrm{~mm}$; left eye, $7 \mathrm{~mm}$ ).

Functionally, the patient had a moderate restrictive pattern (Tiffeneau index, 80; $\mathrm{FEV}_{1}$, 70.9\%; FVC, 66.8\%; TLC, 64.6\%; and RV, $68.4 \%)$, moderately reduced DLCO (51.2\% of predicted), and a short six-minute walk distance with desaturation of $5 \%$.

A surgical lung biopsy showed foci of fibroblast proliferation, macrophages with anthracotic pigmentation and birefringent particles suggestive of silicates, multinucleated giant cells along the bronchoalveolar axes and interlobular septa, as well as alveolar macrophage desquamation and diffuse pleural fibrosis (Figure 2).

A diagnosis of mixed pneumoconiosis due to silica, hard metals, and asbestos, associated with primary Sjögren's syndrome (SS) with possible pulmonary parenchymal involvement, was established. The patient was started on a four-month course of $0.5 \mathrm{mg} / \mathrm{kg}$ prednisolone, which resulted in decreased dyspnea on exertion and complete resolution of the skin lesions, although there was only slight improvement in radiological findings and in DLCO.

The concomitant diagnosis of late-onset primary SS, established in accordance with the criteria proposed by the European American 


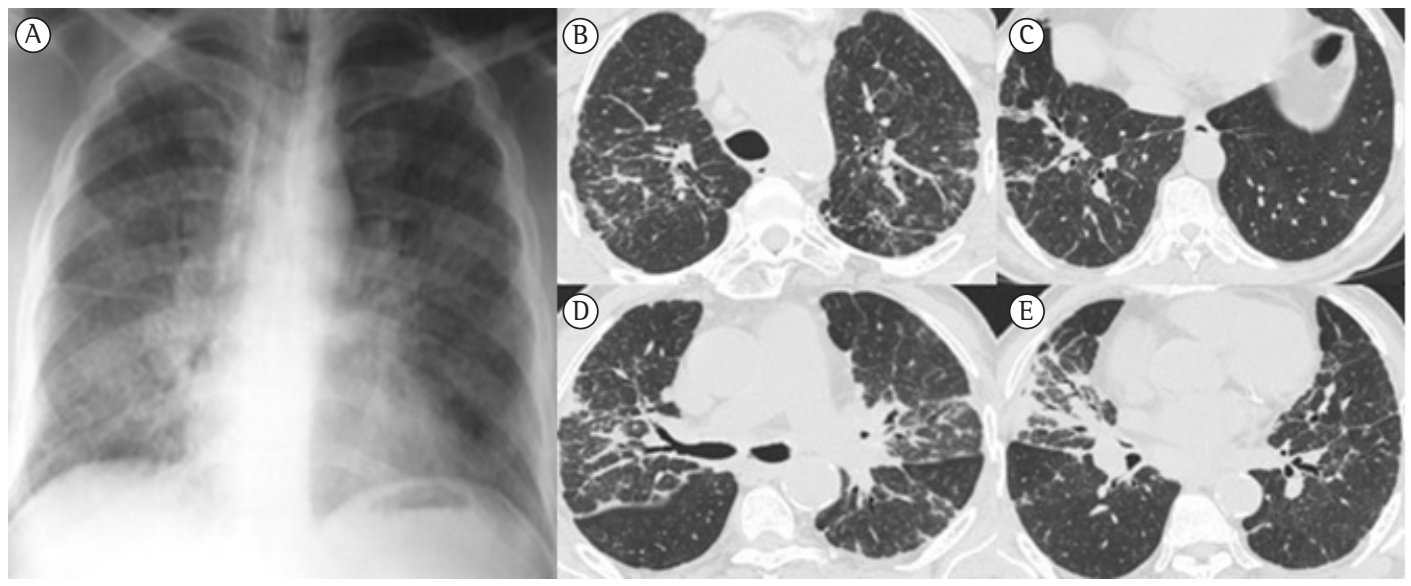

Figure 1 - Initial radiological findings. In A, chest X-ray showing a reticular interstitial pattern predominantly in the lower lung fields, already denoting some loss of volume. In B-E, CT scan showing septal thickening patterns, traction bronchiectasis, small areas of ground-glass opacity, and consolidation with a peribronchovascular distribution.

Consensus Group, may be related to the longterm exposure to silica, which is in agreement with the few existing reports in the literature. (1-3) In fact, it has been shown that intense exposure to silica can lead to the development of autoimmune processes, namely systemic sclerosis, ${ }^{(4)}$ rheumatoid arthritis, ${ }^{(4)}$ and primary SS, ${ }^{(1-4)}$ in a proportion of exposed workers. In this context, alveolar lymphocytosis has been correlated with pulmonary involvement in SS and with unfavorable prognosis..$^{(5)}$ In the present case, the finding of peribronchovascular lymphocytic infiltration with a significant proportion of B lymphocytes may be related to parenchymal infiltration attributable to SS. The correct exclusion of lymphoma was essential.

The pneumoconiotic component, radiologically expressed by inflammatory changes and fibrotic involvement, manifests histologically as a periseptal and peribronchovascular fibroblastic reaction, as well as by the presence of macrophages with anthracotic pigmentation and birefringent particles. The observed patterns of alveolar desquamation and giant cell reaction are the ones that are typically seen in hard metal lung disease. ${ }^{(6-8)}$ The areas of diffuse pleural fibrosis are relatable to exposure to asbestos.

Typical histology of parenchymal disease due to hard metals corresponds to the pattern of interstitial fibrosis with giant cell reaction and foci of desquamative interstitial pneumonia with or without bronchiolitis obliterans. ${ }^{(6-8)}$ In some cases, there can be sarcoid features or only a mixed-dust pneumoconiosis pattern.
Lung mineralogical analysis is useful in the etiological detection of particles in pneumoconiosis. ${ }^{(7)}$ In the present case, the BAL fluid levels of silicates and hard metals were determined by inductively coupled plasma-atomic emission spectrometry. This type of information makes it possible to document occupational exposure, which is often mixed in nature, several decades after exposure was discontinued, assisting in the etiological identification of some occupational respiratory diseases.9. ${ }^{(9)}$ Although direct analysis of lung biopsy/autopsy specimens is the most direct marker to determine particle accumulation, BAL fluid analysis is simpler and yields results that show good agreement with those obtained from tissue specimens. ${ }^{(9)}$ However, biopsy is essential in cases in which the differential diagnosis with sarcoidosis is required.

The hard metals most widely used in industry are tungsten carbide, molybdenum carbide, and chromium carbide-cobalt and nickel being alloying elements-and they can induce antigenspecific immune responses in the lung as well as innate immune responses characterized by inflammation and triggered by oxidative injury. (8) Of the elements detected in patient BAL fluid samples, silica, chromium, molybdenum, cobalt, and zinc have all been associated with lung fibrosis or pneumoconiosis. ${ }^{(10)}$ It is known, however, that high concentrations of particles in tissues or body fluids indicate significant exposure but not necessarily disease. Nevertheless, when used in cases of heavy exposure and suggestive clinical, radiological, and histological findings, such as the present case, determination of the levels of hard 

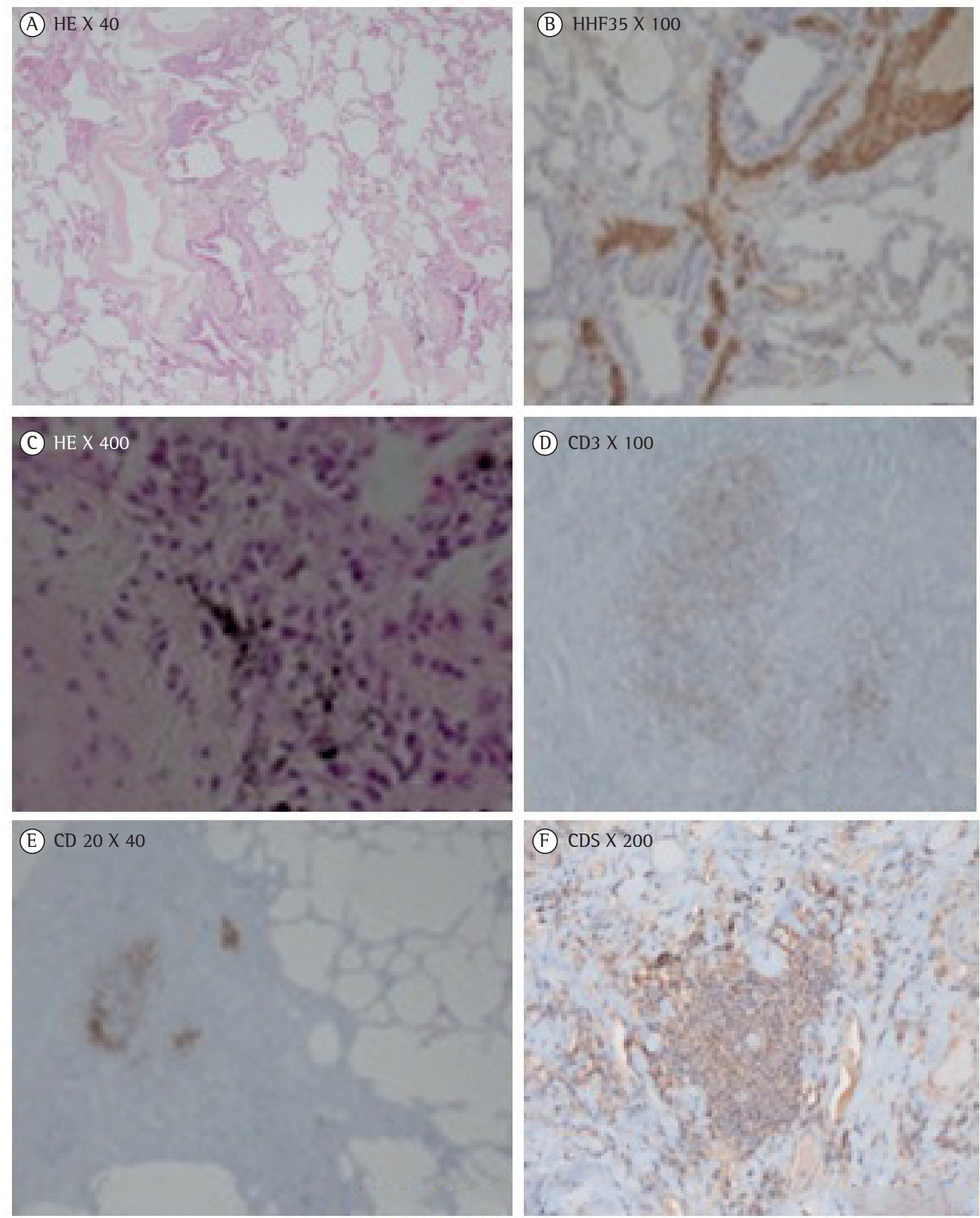

Figure 2 - Photomicrographs of histological sections of surgical lung biopsy specimens. In A, chronic inflammatory infiltrate and septal fibrosing reaction (H\&E; magnification, $\times 40$ ). In $\mathrm{B}$, active fibroblastic foci (HHF35; magnification, $\times 100$ ). In C, macrophages with anthracotic pigmentation and birefringent silica particles, as well as multinucleated giant cells along the bronchoalveolar axes and interlobular septa (HPX; magnification, $\times 400$ ). In D, lymphocytic inflammatory infiltrate with T cells (CD3; magnification, $\times 100)$. In E, foci of B cells (CD20+) in the chronic inflammatory infiltrate (CD20; magnification, $\times 40)$. In $\mathrm{F}$, predominance of T cells with a CD8 immunophenotype (CD8; magnification, $\times 200$ ).

metals is a valuable element in the diagnosis of less common types of pneumoconiosis, as well as in the understanding of their pathogenesis. ${ }^{(7)}$
Given the large number of workers involved, a better understanding of the impacts of exposure to welding fumes on pulmonary function will 
be important for the development of better prevention strategies.

\section{Pedro Gonçalo de Silva Ferreira} Pulmonologist, Coimbra Hospital and University Center, Coimbra, Portugal

\section{António Jorge Correia Gouveia Ferreira Pulmonologist, Coimbra Hospital and University Center, Coimbra, Portugal}

\section{Lina Maria Rodrigues de Carvalho Director, Department of Anatomical Pathology, Coimbra Hospital and University Center, Coimbra, Portugal}

António Segorbe Luís Director, Department of Allergy and Clinical Immunology, Coimbra Hospital and University Center, Coimbra, Portugal

\section{References}

1. Puisieux F, Hachulla E, Brouillard M, Hatron PY, Devulder B. Silicosis and primary Gougerot-Sjögren syndrome [Article in French]. Rev Med Interne. 1994;15(9):575-9. http://dx.doi.org/10.1016/S0248-8663(05)82502-0

2. Astudillo L, Sailler L, Ecoiffier M, Giron J, Couret B, Arlet-Suau E. Exposure to silica and primary Sjögren's syndrome in a dental technician. Rheumatology (0xford). 2003;42(10):1268-9. http://dx.doi.org/10.1093/ rheumatology/keg334 PMid:14508049

3. Kirwan JR. Out-patient workload. Rheumatology (Oxford). 2003;42(10):1269-70. http://dx.doi.org/10.1093/ rheumatology/keg335 PMid:14508050

4. Sanchez-Roman J, Wichmann 1, Salaberri J, Varela JM, Nu-ez-Roldan A. Multiple clinical and biological autoimmune manifestations in 50 workers after occupational exposure to silica. Ann Rheum Dis. 1993;52(7):534-8. http://dx.doi.org/10.1136/ard.52.7.534 PMid:8394065 PMCid:PMC1005094

5. Dalavanga YA, Voulgari PV, Georgiadis AN, Leontaridi C, Katsenos S, Vassiliou M, et al. Lymphocytic alveolitis: A surprising index of poor prognosis in patients with primary Sjogren's syndrome. Rheumatol Int. 2006;26(9):799804. http://dx.doi.org/10.1007/s00296-005-0092-1 PMid:16344933

6. van den Eeckhout AV, Verbeken E, Demedts M. Pulmonary pathology due to cobalt and hard metals [Article in French]. Rev Mal Respir. 1989;6(3):201-7. PMid:2662276

7. Rüttner JR, Spycher MA, Stolkin 1. Inorganic particulates in pneumoconiotic lungs of hard metal grinders. Br J Ind Med. 1987;44(10):657-60. PMid:3676118 PMCid:PMC1007897

8. Kelleher P, Pacheco K, Newman LS. Inorganic dust pneumonias: the metal-related parenchymal disorders. Environ Health Perspect. 2000;108 Suppl 4:685-96. PMid:10931787 PMCid:PMC1637664

9. Dumortier P, De Vuyst P, Yernault JC. Non-fibrous inorganic particles in human bronchoalveolar lavage fluids. Scanning Microsc. 1989;3(4):1207-16; discussion 1217-8. PMid:2561220

10. Selden A, Sahle W, Johansson L, Sorenson S, Persson B. Three cases of dental technician's pneumoconiosis related to cobalt-chromium-molybdenum dust exposure. Chest. 1996;109(3):837-42. http://dx.doi.org/10.1378/ chest.109.3.837 PMid:8617099 